\title{
Pharmacogenetic Approach to Toxicity in Breast Cancer Patients Treated with Taxanes
}

\author{
SILVIA ANGELINI ${ }^{1,2}$, ANDREA BOTTICELLI ${ }^{1}$, CONCETTA ELISA ONESTI $^{1,2}$, \\ RAFFAELE GIUSTI ${ }^{2}$, VALENTINA SINI ${ }^{1,3}$, VALERIA DURANTE ${ }^{1,2}$, LIDIA STRIGARI $^{4}$, \\ GIOVANNA GENTILE ${ }^{5}$, BRUNA CERBELLI $^{6}$, PATRIZIA PELLEGRINI ${ }^{2}$, VALENTINA SGROI ${ }^{1,2}$, \\ MARIO OCCHIPINTI ${ }^{1,2}$, FRANCESCA ROMANA DI PIETRO ${ }^{1,2}$, ALESSANDRO ROSSI $^{7}$, \\ MAURIZIO SIMMACO $^{8}$, FEDERICA MAZZUCA $^{1,2}$ and PAOLO MARCHETTI ${ }^{1,2,5}$ \\ ${ }^{1}$ Department of Clinical and Molecular Medicine, "Sapienza" University of Rome, Rome, Italy; \\ ${ }^{2}$ Department of Medical Oncology, Sant'Andrea Hospital, Rome, Italy; \\ ${ }^{3}$ Santo Spirito Hospital, Lungotevere in Saxia, Rome, Italy; \\ ${ }^{4}$ Laboratory of Medical Physics and Expert Systems, Regina Elena National Cancer Institute, Rome, Italy; \\ ${ }^{5}$ Dermopatic Institute of the Immacolata IDI-IRCSS, Rome, Italy; \\ ${ }^{6}$ Department of Radiological Oncological and Pathological Sciences, "Sapienza" University of Rome, Rome, Italy; \\ ${ }^{7}$ Faculty of Medicine and Psychology, Sapienza" University of Rome, Rome, Italy; \\ ${ }^{8}$ Department of Neurosciences, Mental Health and Sensory Organs (NESMOS), \\ "Sapienza" University of Rome, Rome, Italy
}

\begin{abstract}
Background: Taxanes are widely used to treat breast cancer patients. Taxanes are metabolized in human liver by the cytochrome CYP3A and are substrate of ATP. binding cassette multidrug transporters $A B C B 1$. Singlenucleotide polymorphisms (SNPs) in genes involved in taxanes' metabolism could affect the inter-individual variability in reported toxicities. Materials and Methods: In this retrospective study, 152 women, affected by breast cancer and receiving a taxane-based chemotherapy, were enrolled. A peripheral blood sample was taken for genotyping the following polymorphisms: CYP3A4* $1 B$ $(A>G), C Y P 3 A 5 * 3(G>A)$ and $A B C B 1$ (C1236T; C3435T). Results: We observed an association between $A B C B 13435$ $T / T$ and lower grade of toxicities $(p=0.05)$. No other association were found for $C Y P 3 A 4 * 1 B, 3 A 5 * 3$ and $A B C B 1$ C1236T. Conclusion: ABCBI $3435 \mathrm{~T} / \mathrm{T}$ seems to be associated to lower rate of toxicity in patients receiving taxanes. Further prospective and larger studies should be performed to clarify the role of this polymorphism.
\end{abstract}

Correspondence to: Concetta Elisa Onesti, Department of Medical Oncology, Sant'Andrea Hospital, Via Grottarossa 1035, 00189, Rome, Italy. Tel: +39 0633775699, e-mail: elisaonesti@gmail.com

Key Words: Breast cancer, taxanes, polymorphisms, $A B C B 1$, P-gp, cytochrome P450.
Breast cancer (BC) is the most prevalent malignancy and the leading cause of cancer-related death in women (1). Taxanes are members of microtubule-targeting agents, including two molecules, paclitaxel and docetaxel, widely used for breast cancer treatment in combination with anthracyclines in adjuvant or neoadjuvant setting or in monotherapy in anthracycline-refractory metastatic BC patients (2-5).

Despite the benefit of taxane-based therapy, toxicity management is a key issue to avoid dose reduction and treatment delay or discontinuation. The most common taxanes side-effects are myelosuppression, gastrointestinal toxicities, neuropathy and alopecia $(6,7)$.

In addition to dose-dependent toxicity, the inter-individual differences can be related to non-genetic factors, including age, organ function, concomitant medications and drug interactions. Moreover, the drug effects may relate to polymorphisms in genes encoding drug-metabolizing enzymes and drug transporters (8).

Taxanes are hydroxylated in the liver and eliminated via biliary canaliculi, resulting mostly in fecal excretion and, in a minor extent, in urinary excretion (9).

Human cytochrome P450 family 3, subfamily A (CYP3A), is the most important factor responsible of taxanes' metabolism in the liver. In particular, both docetaxel and paclitaxel are metabolized by CYP3A4, while CYP3A5 is involved in docetaxel catabolism and CYP2C8 in paclitaxel hydroxylation $(10,11)$. 
Table I. Primers for PCR amplification and pyrosequencing.

\begin{tabular}{lccc}
\hline SNPs & Forward primer $\left(5^{\prime}-3^{\prime}\right)$ & Reverse primer $\left(5^{\prime}-3^{\prime}\right)$ & Sequencing primer $\left(5^{\prime}-3^{\prime}\right)$ \\
\hline$A B C B 1$ C1236T & aTCACTCGTCCTGGTAGAT & ATCAGCTGGACTGTTGTG & TGCACCTTCAGGTTCAG \\
$A B C B 1$ C $3435 \mathrm{~T}$ & aATTGCCTATGGAGACAAC & TTACATTAGGCAGTGACTC & CTTTGCTGCCCTCAC \\
$C Y P 3 A 4 * 1 \mathrm{~B}$ & GGGATGAATTTCAAGTAT & aGGGTTCTTATCAGAAACT & CAGCCATAGAGACAAGG \\
$C Y P 3 A 5 * 3$ & CTGCCTTCAATTTTTCACT & aTATGTTATGTAATCCATACCCC & GAGCTCTTTTGTCTTTCA \\
\hline
\end{tabular}

aBiotin molecule attached; PCR, polymerase chain reaction; SNP, single-nucleotide polymorphism.

Taxanes are also a substrate of the adenosine triphosphatebinding cassette $\mathrm{B} 1$ ( $A B C B 1$ gene), a P-glycoprotein (P-gp) membrane-bound efflux pump, which has a crucial role in biliary absorption and intestinal elimination (12).

The single-nucleotide polymorphisms (SNPs) in $A B C B 1$ and CYP P450 (CYP) genes could be associated to interindividual variation. In particular, SNPs in $A B C B 1$ gene are combined with phenotypic differences in P-gp, which play the most important role in drugs clearance $(13,14)$.

In previous studies, multidrug resistence1 (MDR1)/gp170 expression was found in $41.2 \%$ of $\mathrm{BC}$ tumors and an increase during antiblastic treatment was identified. Authors demonstrated that breast cancer patients presenting P-gp expression show three times higher risk to not respond to chemotherapy (15).

The hepatic and intestinal expression of $A B C B 1$ in a normal subject may be due to the highly polymorphic gene with more than 100 SNPs identified, responsible for altered transporter expression and function $(16,17)$.

The most studied polymorphism in $A B C B 1$ gene is the C3435T SNP in exon 26. Wang et al. showed that it is associated to mRNA instability; in particular, the C3435T variant is related to a low level of mRNA as a consequence of his secondary structure (18). The different expression may affect the absorption and the distribution of drugs causing an increase in the plasma concentration $(19,20)$.

Likewise, in literature, $A B C B 1 \mathrm{C} 1236 \mathrm{~T}$ polymorphism in exon 12 is associated with decreased docetaxel clearance (13).

The objectives of the current study were to explore the associations between the known polymorphisms in CYP3A4, $C Y P 3 A 5, A B C B 1$ and drug's toxicity in patients affected by breast cancer.

\section{Materials and Methods}

Patients' selection and monitoring. We enrolled, in a retrospective study, women aged $\geq 18$ years with histologically confirmed $\mathrm{BC}$ treated with taxane-based chemotherapy, admitted at our Institution between 2006 and 2012. Patients underwent a blood sampling for taxanes' pharmacogenetics before starting treatment. An Eastern Cooperative Oncology Group (ECOG) performance status (PS) of $0-2$ and adequate bone marrow, hepatic and renal functions are requested for inclusion in the study. Patients with secondary cancer, recent cardiovascular or metabolic not compensated disease and with peripheral neuropathy of grade 2 or greater before starting treatment were excluded from the study. All patients signed informed consent for enrollment in this retrospective analysis.

Blood examinations were monitored on days 14 and 20 of every chemotherapy cycle. Toxicities were evaluated using common terminology criteria for adverse events (CTCAE v3.0) (21).

Patients were classified in two classes according to adverse events reported: absence or mild toxicity (CTCAE grade $0-2$ ); doselimiting toxicity (CTCAE grade 3-4). The continuation of treatment and the total number of administrations were at the discretion of the physician.

Genotyping. We studied the following DNA polymorphisms: CYP3A4*1B (rs2740574), CYP3A5*3 (rs776746), ABCB1 C1236T (rs1128503), ABCB1 C3435T (rs1045642).

Genomic DNA was isolated from peripheral blood using the $\mathrm{X}$ tractor Gene system (Corbett Life Science, Sydney, Australia). All SNPs were genotyped by pyrosequencing technology (Pyrosequencer PyroMark ID system; Biotage $\mathrm{AB}$ and Biosystems, Uppsala, Sweden). Reverse and forward sequencing primers were obtained by PSQ Assay Design software (Biotage AB and Biosystems). Polymerase chain reaction (PCR) primer pairs and sequencing primers for each SNP are reported in Table I. Briefly, regions covering the SNP of interest were amplified as follows: after initial denaturation $\left(95^{\circ} \mathrm{C}, 1 \mathrm{~min}\right)$, a thermal cycler protocol (40 cycles) was employed cycling $20 \mathrm{~s}$ at $95^{\circ} \mathrm{C}, 25 \mathrm{~s}$ at $56^{\circ} \mathrm{C}$, followed by $30 \mathrm{~s}$ extension at $72^{\circ} \mathrm{C}$; a final extension of $5 \mathrm{~min}$ at $72^{\circ} \mathrm{C}$ was added. All PCR reactions were performed in a final volume of $50 \mu$ containing $40 \mathrm{ng}$ of genomic DNA, $10 \mathrm{pmol}$ of each primer, $0.2 \mathrm{~m}$ dNTPs, the appropriate concentration of $\mathrm{MgCl}_{2}$ (Table I), PCR buffer and $1.5 \mathrm{U}$ of Taq DNA polymerase (Takara Bio Inc. Otsu, Japan).

Single-stranded DNA was isolated from the PCR reaction using the Pyrosequencing Vacuum Prep Workstation (Biotage) and Streptavidin Sepharose ${ }^{\mathrm{TM}}$ High Performance beads (Amersham Biosciences, Uppsala, Sweden) that bind to the biotinylated primer. After washing in $70 \%$ ethanol, incubation in denaturing buffer and flushing with wash buffer, the beads were then released into a 96well plate containing annealing buffer and the specific sequencing primer. Annealing was performed at $80^{\circ} \mathrm{C}$ for 2 min followed by cooling at room temperature. Then real-time sequencing was performed.

Statistical analysis. According to the explorative intent of a retrospective analysis, no formal statistical hypothesis was prespecified and no sample size was pre-defined. Patients' demographics and characteristics of disease were analyzed using 
descriptive statistics. Discrete variables were expressed as number of patients and relative frequencies (percentages), while continuous variables as median and range. The degree of association between G3-4 toxicity and gene polymorphisms were tested with using the Fisher's test. Odds ratio (OR) with $95 \%$ confidence interval (CI) was calculated to quantify the risk factors.

All statistics were calculated using R-Package version 3.1 (https://cran.r-project.org).

\section{Results}

In this study, 152 adult women were enrolled with a median age of 59 years (range $=31-85$ ). Patients' characteristics are shown in Table II. Metastatic disease was present in 53 patients $(34.9 \%)$, while 99 patients $(65.1 \%)$ showed a locally advanced disease. In these last group of patients, $33(21.7 \%)$ received a neoadjuvant treatment and $66(43.4 \%)$ an adjuvant treatment.

G1-2 toxicities were detected in 69 patients $(45.4 \%)$, mainly hematological or gastrointestinal. G3-4 toxicities were detected in 71 patients $(46.7 \%)$. Between patients experiencing G3-4 toxicity, 66.2\% were hematological, $19.7 \%$ gastrointestinal, $11.2 \%$ cutaneous, $7 \%$ asthenia, $5.6 \%$ mucositis, $1.4 \%$ neurotoxicity and $1.4 \%$ of other kind. Toxicity rates in locally advanced and metastatic setting are reported in Table III.

Patients' genotypic variants in our cohort and G3-4 toxicity for each subgroup are shown in Table IV. ABCB1 C3435T shows homozygous mutated variant in 44 patients and $34.1 \%$ of them encountered severe rate-limiting toxicities vs. $44.5 \%$ of CC variant and $54.4 \%$ of CT variant. $A B C B 1 \mathrm{C} 3435 \mathrm{~T}$ homozygous mutant polymorphism seems to be protective from risk of developing severe toxicities with an OR of 0.48 $(p=0.05)$. Conversely, no statistical associations were detected between $A B C B 1$ C1236T, $C Y P 3 A 4 * 1 \mathrm{~B}, \quad C Y P 3 A 5 * 3$ polymorphisms and toxicities. The multiple regression analysis confirms that $A B C B 1 \mathrm{C} 3435 \mathrm{~T}$ is a predictive factor for toxicity not influenced by other genotypic characteristics with a $p$-value of 0.0264 , as shown in Table V.

Finally, we analyzed the association between gene polymorphisms and severe toxicities in the subgroup of 79 patients treated with anthracycline and no statistically significant results were detected $(p=0.36$ for $A B C B 1$ C1236T; $p=0.09$ for $A B C B 1$ C3435T).

\section{Discussion}

The aim of our study was to identify (i) potential associations between polymorphisms in genes encoding for CYP and ABCB1, involved in taxanes' metabolism and transportation, and (ii) toxicity recorded during treatment with taxane-containing regimens in BC patients.

Analysis shows a "genotype-related" association in patients with BC with a lower risk of developing G3-4
Table II. Patients' characteristics and genotypic variants.

\begin{tabular}{|c|c|c|c|}
\hline & & $\begin{array}{l}\text { Number of } \\
\text { patients } \\
\text { (total 152) }\end{array}$ & $\begin{array}{c}\% \text { of } \\
\text { patients }\end{array}$ \\
\hline Age & $\begin{array}{l}\text { Range }=31-85 \text { years } \\
\text { Median }=59 \text { years }\end{array}$ & & \\
\hline Stage & $\begin{array}{l}\text { Locally advanced } \\
\text { Metastatic }\end{array}$ & $\begin{array}{l}99 \\
53\end{array}$ & $\begin{array}{l}65.1 \\
34.9\end{array}$ \\
\hline Setting of treatment & $\begin{array}{l}\text { Neoadjuvant } \\
\text { Adjuvant } \\
\text { Metastatic }\end{array}$ & $\begin{array}{l}33 \\
66 \\
53\end{array}$ & $\begin{array}{l}21.7 \\
43.4 \\
34.9\end{array}$ \\
\hline Type of chemotherapy & $\begin{array}{l}\text { Paclitaxel-based } \\
\text { Docetaxel-based } \\
\text { Nab-paclitaxel-based }\end{array}$ & $\begin{array}{c}28 \\
123 \\
1\end{array}$ & $\begin{array}{c}18.4 \\
80.9 \\
0.7\end{array}$ \\
\hline$A B C B 1 \mathrm{C} 3435 \mathrm{~T}$ & $\begin{array}{l}\mathrm{CC} \\
\mathrm{CT} \\
\mathrm{TT}\end{array}$ & $\begin{array}{l}68 \\
40 \\
44\end{array}$ & $\begin{array}{l}44.7 \\
26.3 \\
28.9\end{array}$ \\
\hline$A B C B 1 \mathrm{C} 1236 \mathrm{~T}$ & $\begin{array}{l}\mathrm{CC} \\
\mathrm{CT} \\
\mathrm{TT}\end{array}$ & $\begin{array}{l}68 \\
43 \\
41\end{array}$ & $\begin{array}{l}44.7 \\
28.3 \\
27.0\end{array}$ \\
\hline CYP $3 A 5 * 3 \mathrm{~A}>\mathrm{G}$ & $\begin{array}{l}\text { AA } \\
\text { AG } \\
\text { GG }\end{array}$ & $\begin{array}{c}16 \\
134 \\
1\end{array}$ & $\begin{array}{c}10.5 \\
88.2 \\
0.7\end{array}$ \\
\hline$C Y P 3 A 4 * 1 \mathrm{~B} \quad \mathrm{~A}>\mathrm{G}$ & $\begin{array}{l}\text { AA } \\
\text { AG } \\
\text { GG }\end{array}$ & $\begin{array}{c}9 \\
142 \\
1\end{array}$ & $\begin{array}{c}5.9 \\
93.4 \\
0.7\end{array}$ \\
\hline
\end{tabular}

toxicity in $A B C B 1 \mathrm{C} 3435 \mathrm{~T}$ genotypes $\mathrm{T} / \mathrm{T}$ compared to $\mathrm{C} / \mathrm{C}$ and $\mathrm{C} / \mathrm{T}$. The absence of statistical association in $C Y P$ SNPs is probably due to the small number of patients carrying mutated variants, in line with allele frequencies in Caucasian population (22).

Literature data are controversial in this field due to the lack of adequate studies, small sample size or heterogeneity of populations analyzed (23-33). Table VI summarizes an overview of the studies performed during the last ten years analyzing $A B C B 1 \mathrm{C} 3435 \mathrm{~T}, A B C B 1 \mathrm{C} 1236 \mathrm{~T}, C Y P 3 A 4 * 1 \mathrm{~B}$ and $C Y P 3 A 5^{*} 3$ polymorphisms and including more than 50 patients. Studies with smaller sample size due to lower statistical power were excluded. The majority of the studies were exploratory data analysis of patients enrolled in trials with different end-point $(23,24,28,30,32)$ or retrospective series $(26,29)$. In fact, only three prospective trials are reported in literature $(25,27,31)$. Kim and colleagues published in 2012 and 2015 two analyses on breast cancer patients, finding an association between $A B C B 13435 \mathrm{~T} / \mathrm{T}$ and G3-4 toxicity $(23,25)$. In the last paper, the authors included patients treated with anthracycline that could influence results (25). Abraham and colleagues found an association between neurotoxicity and $A B C B 13435 \mathrm{~T} / \mathrm{T}$ genotype, analyzing various paclitaxel-based regimens and considering only neurological toxicity (24). In concordance to our results, Tsai and colleagues found higher frequency 
Table III. Toxicity classification.

\begin{tabular}{|c|c|c|c|c|c|c|c|c|}
\hline & \multicolumn{4}{|c|}{ Locally advanced $(\mathrm{n}=99)$} & \multicolumn{4}{|c|}{ Metastatic $(\mathrm{n}=53)$} \\
\hline & \multicolumn{2}{|c|}{ G1-2 toxicity } & \multicolumn{2}{|c|}{ G3-4 toxicity } & \multicolumn{2}{|c|}{ G1-2 toxicity } & \multicolumn{2}{|c|}{ G3-4 toxicity } \\
\hline & $\mathrm{n}$ & $\% / 99$ patients & $\mathrm{n}$ & $\% / 99$ patients & $\mathrm{n}$ & $\% / 53$ patients & $\mathrm{n}$ & $\% / 53$ patients \\
\hline Hematological & 22 & 22.2 & 41 & 41.4 & 16 & 30.2 & 6 & 11.3 \\
\hline Gastrointestinal & 47 & 47.5 & 9 & 9.1 & 11 & 20.8 & 5 & 9.4 \\
\hline Asthenia & 30 & 30.3 & 3 & 3 & 15 & 28.3 & 2 & 3.8 \\
\hline Neurotoxicity & 44 & 44.4 & 0 & 0 & 25 & 47.2 & 1 & 1.9 \\
\hline Mucositis & 9 & 9.1 & 3 & 3 & 8 & 15.1 & 1 & 1.9 \\
\hline Cutaneous & 9 & 9.1 & 3 & 3 & 4 & 7.5 & 5 & 9.4 \\
\hline Hepatic & 2 & 2 & 0 & 0 & 1 & 1.9 & 0 & 0 \\
\hline Other & 16 & 16.2 & 1 & 1 & 7 & 13.2 & 0 & 0 \\
\hline
\end{tabular}

Table IV. Associations between G3-4 toxicity and gene polymorphisms.

\begin{tabular}{|c|c|c|c|c|c|c|}
\hline & & \multicolumn{2}{|c|}{ G3-4 toxicity } & \multirow[t]{2}{*}{ Type of comparison } & \multirow[t]{2}{*}{ OR } & \multirow[t]{2}{*}{$p$-Value } \\
\hline & & Number of patients & $\%$ & & & \\
\hline \multirow[t]{3}{*}{$A B C B 1 \mathrm{C} 3435 \mathrm{~T}$} & $\mathrm{CC}$ & 19 & 47.5 & $\mathrm{TT} v s . \mathrm{CC} / \mathrm{CT}$ & 0.48 & $0.05^{*}$ \\
\hline & $\mathrm{CT}$ & 37 & 54.4 & & & \\
\hline & TT & 15 & 34.1 & & & \\
\hline \multirow[t]{3}{*}{$A B C B 1 \mathrm{C} 1236 \mathrm{~T}$} & $\mathrm{CC}$ & 19 & 44.2 & $\mathrm{TT} v s . \mathrm{CC} / \mathrm{CT}$ & 0.98 & 1 \\
\hline & $\mathrm{CT}$ & 33 & 48.5 & & & \\
\hline & TT & 19 & 46.3 & & & \\
\hline \multirow[t]{3}{*}{ CYP $3 A 5 * 3 \mathrm{~A}>\mathrm{G}$} & AA & 66 & 49.3 & GG $v s . \mathrm{AA} / \mathrm{AG}$ & 0 & 1 \\
\hline & $\mathrm{AG}$ & 5 & 31.2 & & & \\
\hline & GG & 0 & 0 & & & \\
\hline \multirow[t]{3}{*}{ CYP $3 A 4 * 1 \mathrm{~B}$ A $>\mathrm{G}$} & AA & 67 & 47.2 & GG $v s . \mathrm{AA} / \mathrm{AG}$ & 0 & 1 \\
\hline & $\mathrm{AG}$ & 4 & 44.4 & & & \\
\hline & GG & 0 & 0 & & & \\
\hline
\end{tabular}

OR, Odds ratio; *Fisher's test.

of hematological toxicity in breast cancer patients treated with docetaxel-epirubicin-cyclophosphamide (TEC) regimen carrying the $A B C B 13435 \mathrm{C} / \mathrm{C}$ variant compared to genotypes containing at least one $\mathrm{T}$ allele $(p=0.057)$ (29). Likewise, Gandara and colleagues found a trend for $A B C B 13435 \mathrm{C}$ allele towards increased risk to develop G4 neutropenia $(p=0.19)$ (30). Previous studies analyzing mRNA level showed that $A B C B 13435 \mathrm{CC}$ genotype was usually associated with higher levels of mRNA for the transporter and, consequently, increased drug's efflux and reduced amount of drug in plasma with a lower rate of toxicities (34). Nakamura et al. reported the effect of the C3435T polymorphism on MDRI mRNA levels. In this study, conducted by analyzing 51 histological specimens of 13 Japanese healthy subjects, the authors found a greater concentration of MDRl mRNA in T/T genotype compared
Table V. Multiple regression analysis for toxicity including all genotype groups for 152 breast cancer patients treated with taxanes.

\begin{tabular}{lrcc}
\hline Coefficients & Estimate & Standard error & $p$-Value \\
\hline (Intercept) & 0.48725 & 0.16563 & 0.0038 \\
$A B C B 1$ C1236T & 0.04473 & 0.05690 & 0.4331 \\
$A B C B 1$ C3435T & -0.12433 & 0.05543 & 0.0264 \\
CYP3A5*3 & 0.20889 & 0.14811 & 0.1606 \\
CYP3A4*1B & -0.14558 & 0.18637 & 0.4360 \\
\hline
\end{tabular}

to $\mathrm{C} / \mathrm{C}$ and $\mathrm{C} / \mathrm{T}$. Moreover, a relation between $M D R 1$ and CYP3A4 mRNA amount in individual biopsy, suggesting an interaction in different genes' expression (35), was observed. 
Table VI. Overview of the last ten-year pharmacogentic studies, including the evaluation of ABCB1,CYP3A4*1B and CYP3A5*3 SNPs, taxanebased treatment and toxicity in cancer patients.

\begin{tabular}{|c|c|c|c|c|c|c|c|}
\hline Reference & $\begin{array}{l}\text { Type of } \\
\text { study }\end{array}$ & End-point & $\begin{array}{l}\text { Cancer } \\
\text { type }\end{array}$ & $\begin{array}{l}\text { Number of } \\
\text { patients }\end{array}$ & Setting & $\begin{array}{l}\text { Type of } \\
\text { treatment }\end{array}$ & Findings \\
\hline $\begin{array}{l}\text { Kim et al. } \\
2015 \text { (23) }\end{array}$ & $\begin{array}{l}\text { Exploratory } \\
\text { analysis }\end{array}$ & $\begin{array}{l}\text { Pathological } \\
\text { complete } \\
\text { response }\end{array}$ & Breast & 216 & $\begin{array}{l}\text { Neoadjuvant } \\
\text { and } \\
\text { adjuvant }\end{array}$ & $\begin{array}{c}\text { TXT- } \\
\text { Doxorubicin }\end{array}$ & $\begin{array}{c}A B C B 13435 \text { TT: higher frequency } \\
\text { of G3-4 toxicities ( } p=0.037 \text { for } \\
\text { neutropenia and } p=0.017 \text { for diarrhea) }\end{array}$ \\
\hline $\begin{array}{l}\text { Abraham et al. } \\
2014 \text { (24) }\end{array}$ & $\begin{array}{l}\text { Exploratory } \\
\text { analysis }\end{array}$ & TRSN & Breast & 1303 & $\begin{array}{c}\text { Neadjuvant } \\
\text { and adjuvant }\end{array}$ & $\begin{array}{l}\text { Ptx-based } \\
\text { regimen }\end{array}$ & $\begin{array}{c}\text { Decreased risk of TSRN: } \\
A B C B 1 \mathrm{C} 129 \mathrm{C}(p=0.004) \\
\text { Increased risk of TRSN: } A B C B 1 \\
\text { G2677T }(p=0.02) ; A B C B 1 \mathrm{C} 3435 \mathrm{~T} \\
(p=0.03) ; \mathrm{TUBB} 2 \mathrm{~A} \mathrm{~A} 157 \mathrm{G}(p=0.005) ; \\
\text { CYP2C } 8 * 4 \mathrm{G}>\mathrm{C}(p=0.05)\end{array}$ \\
\hline $\begin{array}{l}\text { Kim et al. } \\
2012(25)\end{array}$ & Prospective & Toxicity & Breast & 218 & Adjuvant & TXT & $\begin{array}{c}A B C B 13435 \mathrm{TT} \text { : increased } \\
\text { risk of neutropenia }(p=0.015)\end{array}$ \\
\hline $\begin{array}{l}\text { Leskela } \text { et al. } \\
2011 \text { (26) }\end{array}$ & $\begin{array}{l}\text { Retrospective } \\
\text { and } \\
\text { prospective }\end{array}$ & Neurotoxicity & $\begin{array}{l}\text { Solid } \\
\text { tumors }\end{array}$ & 118 & $\begin{array}{l}\text { Neoadjuvant, } \\
\text { adjuvant and } \\
\text { advanced }\end{array}$ & $\begin{array}{l}\text { Ptx-based } \\
\text { regimen }\end{array}$ & $\begin{array}{c}\text { Increased risk: } \\
C Y P 2 C 8^{*} 3 \mathrm{G}>\mathrm{A}(p=0.032) . \\
\text { Decreased risk: } C Y P 2 C 8 \mathrm{G}>\mathrm{C}(p=0.014) ; \\
C Y P 3 A 5^{*} 3 \mathrm{~A}>\mathrm{G}(p=0.012) .\end{array}$ \\
\hline $\begin{array}{l}\text { Bergman et al. } \\
2011 \text { (27) }\end{array}$ & Prospective & Toxicity & Ovarian & 92 & $\begin{array}{l}\text { Adjuvant and } \\
\text { advanced }\end{array}$ & $\begin{array}{l}\text { CBDCA- } \\
\text { Ptx }\end{array}$ & $\begin{array}{l}\text { Neutrophil decrease: } A B C B 13435 \mathrm{~T} \text { and } \\
\text { TT }(p=0.03) ; A B C B 12677 \mathrm{~T}(p=0.02) .\end{array}$ \\
\hline $\begin{array}{l}\text { Bergman et al. } \\
2011 \text { (28) }\end{array}$ & $\begin{array}{l}\text { Exploratory } \\
\text { analysis }\end{array}$ & $\begin{array}{l}\text { Toxicity and } \\
\text { survival }\end{array}$ & Ovarian & 119 & $\begin{array}{l}\text { Adjuvant and } \\
\text { advanced }\end{array}$ & CBDCA-Ptx & No statistically significant associations \\
\hline Tsai et al. (29) & Retrospective & Toxicity & Breast & 59 & Adjuvant & TEC & $\begin{array}{l}\text { Increased risk hematological toxicity: } \\
\text { CYP3A5*3 A }>\mathrm{G}(\mathrm{p}<0.05) ; A B C B 13435\end{array}$ \\
\hline $\begin{array}{l}\text { Gandara et al. } \\
2009(30)\end{array}$ & $\begin{array}{l}\text { Exploratory } \\
\text { analysis }\end{array}$ & $\begin{array}{l}\text { PFS and } \\
\text { OS }\end{array}$ & Lung & 381 & Advanced & $\begin{array}{l}\text { CBDCA- } \\
\text { Ptx }\end{array}$ & $\begin{array}{c}\mathrm{CC}(p>0.057) ; A B C B 12677 \mathrm{GG}(p=0.024) . \\
\quad \text { No statistically significant associations }\end{array}$ \\
\hline $\begin{array}{l}\text { Chang et al. } \\
2009(31)\end{array}$ & Prospective & $\begin{array}{l}\text { Tumor } \\
\text { response, } \\
\text { OS, toxicity, } \\
\text { chemoresistance }\end{array}$ & Breast & 108 & Advanced & Ptx & No statistically significant associations \\
\hline $\begin{array}{l}\text { Marsh et al. } \\
2007 \text { (32) }\end{array}$ & $\begin{array}{l}\text { Exploratory } \\
\text { analysis }\end{array}$ & $\begin{array}{l}\text { PFS, } \\
\text { toxicity }\end{array}$ & Ovarian & 914 & Advanced & $\begin{array}{l}\text { CBDCA- } \\
\text { Ptx/TXT }\end{array}$ & No statistically significant associations \\
\hline
\end{tabular}

TXT, Docetaxel; TRSN, taxane-related sensory neurophaty; Ptx, paclitaxel; CBDCA, carboplatin; Epi, epirubicin; TEC, docetaxel-epirubicincyclophosphamide.

The most credible hypothesis states that there are compensatory mechanisms outflow of drugs, perhaps through ABCC2 (MRP2) and other uncommon transporters, which would regulate the hepatic elimination of taxanes in patients with altered function of $A B C B 1$. Furthermore, there is a wide interaction between different genes involved in taxanes' metabolism and excretion, as well as ABCB1 membrane transporter polymorphisms (4 at least; T-129C, A61G, C1236T, G2677A) and various CYPs involved in hepatic metabolism $(C Y P 3 A 4 * 1 \mathrm{~B} \mathrm{~A}>\mathrm{G}, C Y P 3 A 5 * 3 \mathrm{G}>\mathrm{A}$ and $C Y P 2 C 8)$ (36). Thus, a possible explanation of our results is that in the $\mathrm{T} / \mathrm{T}$ genotype, the compensatory mechanisms are amplified.

The retrospective design of this study, the small sample size and the heterogeneity for stage and antiblastic regimen used are the main limitations of our study.

Furthermore, it is important to underline that patients' comorbidity, especially in the elderly, is due to the use of concomitant drugs that could increase or decrease toxicity effects of chemotherapy; hence, the study of metabolic pathways and drugs' interactions should be introduced as clinical practice.

In a previous study, analysis of minor DPYD polymorphisms allowed us to increase the power of 5fluorouracil (5-FU)-predicted toxicities. Therefore, this method could be adopted also in the study of taxanes' toxicities, in order to consider also the less frequent SNPs of $A B C B 1$ and $C Y P 3 A 4-5$ (37).

In conclusion, in the context of controversial literature, our study highlights the importance of pre-emptive pharmacogenomics evaluation to prevent severe toxicities and increase compliance to treatment. Further prospective and larger studies could help to clarify the role of these polymorphisms. In addition, analysis of other variants is necessary to better understand the possible compensatory expression of each gene. 


\section{References}

1 Forouzanfar MH, Foreman KJ, Delossantos AM, Lozano R, Lopez AD, Murray CJ and Naghavi M: Breast and cervical cancer in 187 countries between 1980 and 2010: A systematic analysis. Lancet 378(9801): 1461-1484, 2011.

2 National Comprehensive Cancer Network. Clinical Practice Guidelines in Oncology: Breast Cancer, version 1, 2016. Available at URL: http://www.ncen.org/professionals/ physician_gls/pdf/breast.pdf

3 Bines J, Earl H, Buzaid AC and Saad ED: Anthracyclines and taxanes in the neo/adjuvant treatment of breast cancer: Does the sequence matter? Ann Oncol 25(6): 1079-1085, 2014.

4 Chan S, Friedrichs K, Noel D, Pintér T, Van Belle S, Vorobiof D, Duarte R, Gil Gil M, Bodrogi I, Murray E, Yelle L, von Minckwitz G, Korec S, Simmonds P, Buzzi F, González Mancha R, Richardson G, Walpole E, Ronzoni M, Murawsky M, Alakl M, Riva A, Crown J and 303 Study Group: Prospective randomized trial of docetaxel versus doxorubicin in patients with metastatic breast cancer. J Clin Oncol 17(8): 2341-2354, 1999.

5 Ford HE, Yap YS, Miles DW, Makris A, Hall M, Miller L, Harries M, Smith IE and Johnston SR: A phase II study of weekly docetaxel in patients with anthracycline pretreated metastatic breast cancer. Cancer Chemother Pharmacol 58(6): 809-815, 2006.

6 Lee JJ and Swain SM: Peripheral neuropathy induced by microtubule-stabilizing agents. J Clin Oncol 24(10): 1633-1642, 2006.

7 Hagiwara $\mathrm{H}$ and Sunada Y: Mechanism of taxane neurotoxicity. Breast Cancer 11(1): 82-85, 2004.

8 Evans WE and McLeod HL: Pharmacogenomics-drug disposition, drug targets, and side-effects. N Engl J Med 348(6): 538-549, 2003.

9 Gligorov J and Lotz JP: Preclinical pharmacology of the taxanes: Implications of the differences. Oncologist 9(Suppl 2): 3-8, 2009.

10 Shou M, Martinet M, Korzekwa KR, Krausz KW, Gonzalez FJ and Gelboin HV: Role of human cytochrome P450 3A4 and 3A5 in the metabolism of taxotere and its derivatives: Enzyme specificity, interindividual distribution and metabolic contribution in human liver. Pharmacogenetics 8(5): 391-401, 1998.

11 Cresteil T, Monsarrat B, Dubois J, Sonnier M, Alvinerie P and Gueritte F: Regioselective metabolism of taxoids by human CYP3A4 and 2C8: Structure-activity relationship. Drug Metab Dispos 30(4): 438-445, 2002.

12 van Zuylen L, Verweij J, Nooter K, Brouwer E, Stoter G and Sparreboom A: Role of intestinal P-glycoprotein in the plasma and fecal disposition of docetaxel in humans. Clin Cancer Res 6(7): 2598-2603, 2000.

13 Bosch TM, Huitema AD, Doodeman VD, Jansen R, Witteveen E, Smit WM, Jansen RL, van Herpen CM, Soesan M, Beijnen JH and Schellens JH: Pharmacogenetic screening of CYP3A and $\mathrm{ABCB} 1$ in relation to population pharmacokinetics of docetaxel. Clin Cancer Res 12(19): 5786-5793, 2006.

14 Gréen H, Söderkvist P, Rosenberg P, Horvath G and Peterson C: MDR-1 single-nucleotide polymorphisms in ovarian cancer tissue: G2677T/A correlates with response to paclitaxel chemotherapy. Clin Cancer Res 12(3 Pt 1): 854-859, 2006.

15 Trock BJ, Leonessa F and Clarke R: Multidrug resistance in breast cancer: A meta-analysis of MDR1/gp170 expression and its possible functional significance. J Natl Cancer Inst 89(13): 917-931, 1997.
16 Meier Y, Pauli-Magnus C, Zanger UM, Klein K, Schaeffeler E, Nussler AK, Nussler N, Eichelbaum M, Meier PJ and Stieger B: Interindividual variability of canalicular ATP-binding-cassette (ABC)-transporter expression in human liver. Hepatology 44: 62-74, 2006.

17 Thörn M, Finnström N, Lundgren S, Rane A and Lööf L: Cytochromes P450 and MDR1 mRNA expression along the human gastrointestinal tract. Br J Clin Pharmacol 60(1): 54-60, 2005.

18 Wang D, Johnson AD, Papp AC, Kroetz DL and Sadée W: Multidrug resistance polypeptide 1 (MDR1, ABCB1) variant $3435 \mathrm{C}>\mathrm{T}$ affects mRNA stability. Pharmacogenet Genomics 15(10): 693-704, 2005.

19 Rollason V, Samer C, Piguet V, Dayer P and Desmeules J: Pharmacogenetics of analgesics: Toward the individualization of prescription. Pharmacogenomics 9(7): 905-933, 2005.

20 Kim RB: MDR1 single-nucleotide polymorphisms: Multiplicity of haplotypes and functional consequences. Pharmacogenetics 54: 592-603, 2002.

21 Trotti A, Colevas AD, Setser A, Rusch V, Jaques D, Budach V, Langer C, Murphy B, Cumberlin R, Coleman CN and Rubin P: CTCAE v3.0: Development of a comprehensive grading system for the adverse effects of cancer treatment. Semin Radiat Oncol 13(3): 176-181, 2003.

22 Bosch TM, Meijerman I, Beijnen JH and Schellens JH: Genetic polymorphisms of drug-metabolizing enzymes and drug transporters in the chemotherapeutic treatment of cancer. Clin Pharmacokinet 45: 253-285, 2006.

23 Kim HJ, Im SA, Keam B, Ham HS, Lee KH, Kim TY, Kim YJ, Oh DY, Kim JH, Han W, Jang IJ, Kim TY, Park IA and Noh DY: $\mathrm{ABCB} 1$ polymorphism as prognostic factor in breast cancer patients treated with docetaxel and doxorubicin neoadjuvant chemotherapy. Cancer Sci 106(1): 86-93, 2015.

24 Abraham JE, Guo Q, Dorling L, Tyrer J, Ingle S, Hardy R, Vallier AL, Hiller L, Burns R, Jones L, Bowden SJ, Dunn JA, Poole CJ, Caldas C, Pharoah PP and Earl HM: Replication of genetic polymorphisms reported to be associated with taxanerelated sensory neuropathy in patients with early breast cancer treated with paclitaxel. Clin Cancer Res 20(9): 2466-2475, 2014.

25 Kim KP, Ahn JH, Kim SB, Jung KH, Yoon DH, Lee JS and Ahn $\mathrm{SH}$ : Prospective evaluation of the drug-metabolizing enzyme polymorphisms and toxicity profile of docetaxel in Korean patients with operable lymph node-positive breast cancer receiving adjuvant chemotherapy. Cancer Chemother Pharmacol 69: 1221-1227, 2012.

26 Leskelä S, Jara C, Leandro-García LJ, Martínez A, García-Donas J, Hernando S, Hurtado A, Vicario JC, Montero-Conde C, Landa I, López-Jiménez E, Cascón A, Milne RL, Robledo M and RodríguezAntona C: Polymorphisms in cytochromes P450 2C8 and 3A5 are associated with paclitaxel neurotoxicity. Pharmacogenomics $\mathrm{J} 11$ : 121-129, 2011.

27 Bergmann TK, Brasch-Andersen C, Gréen H, Mirza MR, Skougaard K, Wihl J, Keldsen N, Damkier P, Peterson C, Vach W and Brøsen K: Impact of ABCB 1 variants on neutrophil depression: A pharmacogenomic study of paclitaxel in 92 women with ovarian cancer. Basic Clin Pharmacol Toxicol 110: 199-204, 2011.

28 Bergmann TK, Gréen H, Brasch-Andersen C, Mirza MR, Herrstedt J, Hølund B, du Bois A, Damkier P, Vach W, Brosen K and Peterson C: Retrospective study of the impact of pharmacogenetic variants on paclitaxel toxicity and survival in patients with ovarian cancer. Eur J Clin Pharmacol 67(7): 693-700, 2011. 
29 Tsai SM, Lin CY, Wu SH, Hou LA, Ma H, Tsai LY and Hou MF: Side-effects after docetaxel treatment in Taiwanese breast cancer patients with CyP3A4, CYP3A5, and ABCB1 gene polymorphisms. Clin Chim Acta 404(2): 160-165, 2009.

30 Gandara DR, Kawaguchi T, Crowley J, Moon J, Furuse K, Kawahara M, Teramukai S, Ohe Y, Kubota K, Williamson SK, Gautschi O, Lenz HJ, McLeod HL, Lara PN Jr, Coltman CA Jr, Fukuoka M, Saijo N, Fukushima M and Mack PC: Japanese-US common-arm analysis of paclitaxel plus carboplatin in advanced non-small-cell lung cancer: A model for assessing populationrelated pharmacogenomics. J Clin Oncol 27(21): 3540-3546, 2009.

31 Chang H, Rha SY, Jeung HC, Im CK, Ahn JB, Kwon WS, Yoo NC, Roh JK and Chung HC: Association of the ABCB1 gene polymorphisms $2677 \mathrm{G}>\mathrm{T} / \mathrm{A}$ and $3435 \mathrm{C}>\mathrm{T}$ with clinical outcomes of paclitaxel monotherapy in metastatic breast cancer patients. Ann Oncol 20(2): 272-277, 2009.

32 Marsh S, Paul J, King CR, Gifford G, McLeod HL and Brown R: Pharmacogenetic assessment of toxicity and outcome after platinum plus taxane chemotherapy in ovarian cancer: The Scottish Randomised Trial in Ovarian Cancer. J Clin Oncol 25(29): 4528-4535, 2007.

33 Sissung TM, Mross K, Steinberg SM, Behringer D, Figg WD, Sparreboom A and Mielke S: Association of ABCB1 genotypes with paclitaxel-mediated peripheral neuropathy and neutropenia. Eur J Cancer 42(17): 2893-2896, 2006.
34 De Iuliis F, Salerno G, Taglieri L and Scarpa S: Are pharmacogenomic biomarkers an effective tool to predict taxane toxicity and outcome in breast cancer patients? Literature review. Cancer Chemother Pharmacol 76(4): 679-690, 2015.

35 Nakamura T, Sakaeda T, Horinouchi M, Tamura T, Aoyama N, Shirakawa T, Matsuo M, Kasuga M and Okumura K: Effect of the mutation (C3435T) at exon 26 of the MDR1 gene on expression level of MDR1 messenger ribonucleic acid in duodenal enterocytes of healthy Japanese subjects. Clin Pharmacol Ther 71(4): 297-303, 2002.

36 Henningsson A, Marsh S, Loos WJ, Karlsson MO, Garsa A, Mross K, Mielke S, Viganò L, Locatelli A, Verweij J, Sparreboom A and McLeod HL: Association of CYP2C8, CYP3A4, CYP3A5, and $\mathrm{ABCB} 1$ polymorphisms with the pharmacokinetics of paclitaxel. Clin Cancer Res 11(22): 8097-8104, 2005.

37 Gentile G, Botticelli A, Lionetto L, Mazzuca F, Simmaco M, Marchetti P and Borro M: Genotype-phenotype correlations in 5-fluorouracil metabolism: A candidate DPYD haplotype to improve toxicity prediction. Pharmacogenomics J 16(4): 320$325,2016$.
Received March 2, 2017

Revised March 23, 2017

Accepted March 24, 2017 